\title{
Using technology in teaching and learning
}

\section{Resources to help you navigate a digital world}

H umans have been teaching and learning by technology since Socrates rst complained about it in the 4th century BCE Phaedrus. Now that we are into the second decade of the Web and the Internet s second generation, we have seen a wide range of practices emerge for teaching and learning with technology. As technologies have proliferated and developed, teachers have developed and shared techniques and projects through networks and institutions. In this cyberspatial milieu, students have been guinea pigs and innovators, taking classes, experiencing projects, helping teachers and staff support instructors teach, graduating as alumni, and sometimes returning as staff.

Learning and teaching practices have drawn on larger cultural transformations and affordances enabled by cyberculture. For example, the enormous explosion in popularly generated Web content from personal home pages to Amazon book reviews has demonstrated the viability of Sir Tim Berners-Lee s invention for creative expression, leading to millions of pages created by students and instructors.

The decades-long successes of discussion groups (Usenet through Google Groups) and e-mail have shown the utility of asynchronous conversation, which was rapidly incorporated into class discussions. The ease of creating presentations in PowerPoint, combined with their vast popularity in the business and governmental worlds, has led to vast numbers of multimedia slideshows in the hands of teachers and students. The sheer size and accessibility of cyberculture has transformed teaching and doing research at every educational level.
Several factors combine to make exploring this technopedagogical record dif cult. One is the tradition of classroom privacy, which can cloak projects and discussion. Another is the dif culty of sharing information across campus populations. Public anxieties about technology, fueled by media stories and, occasionally, politicians, play a role in sapping discourse. More recently, the tendency to publish course content to venues closed to the public further clouds the eld. Nevertheless, enough work has surfaced and been discussed that a set of teaching principles or themes can be identi ed, thanks largely to the collaborative ethos of the educational technology profession. We can also distinguish practices, projects, and services by types of computer-mediated communication.

\section{Themes}

Learning materials published to the Web, or some network, have supplemented other class materials. Lectures in transcription or sound les, video clips of chemical processes, molecular animations, y-bys through historical structures all have in common several features. By being accessible outside of class time, they can be experienced on a student $s$ schedule. That experience can partake of many digital features that differ from some of the analogue world, such as repeatability (replaying a video), scrubbing (rerunning a

Bryan Alexander is research director for the National Institute for Technology and Liberal Education, e-mail: bryan.alexander@nitle.org

○ 2007 Bryan Alexander 
dif cult passage in a new language), segmentation (focusing on one page from a site), and transferability (a phrase copied from CD-ROM text into e-mail to instructor). Instructors can partake of the digital medium s uidity, reiterating and tweaking objects over time.

The social nature of this media experience has been underappreciated until recently. We inherit many assumptions that individuals experience items in isolation, derived from other media (film, TV, games), linguistic habits ( You are talking on the phone! rather than You are talking with your friend ), and schools of technological criticism arguing that machines separate, rather than connect, people. Networked computing has proven, in fact, to be quite the opposite a social enabler. The Internet has linked people from the beginning, to the extent that the relatively recent term social software purports to restore some of the Internet $s$ original intention. Even more recently, the rise of massively multiplayer online gaming has returned the social nature of networked computing to popular discussion.

In education, this social nature has been one of the major virtues of digital technologies. Discussion boards (Usenet, PHPBB) and fora (WebBoard, Caucus), e-mail, instant messenger, groupware, and course management systems (CMSes, Blackboard, WebCT, Moodle, Sakai) have supported threaded and unthreaded conversations among students both geographically copresent and dispersed. Web 2.0 technologies have enabled different discussion forms, such as distributed conversations (blogs), conversations embedded within documents (wikis), and threads attached to social objects (Flickr).

These conversations have sometimes been distinguished by their temporal nature, asynchronous (discussion boards, blogs) versus synchronous (chat, Second Life, IM). Discussions in both forms have connected members of a class to each other, students to instructors, and students with learners elsewhere.

Both of these themes constitute a continuum of sociability and objects, with most digital learning occurring with some combination of both. For example, a discussion thread may begin with a reference to an online reading, or constitute responses to a Flickr image. The continuum may map onto nondigital materials and venues, as when a digital object sparks a classroom face-to-face discussion, or watching a play provokes blog posts followed by comments. Moreover, projects may scale up from individual cases along this continuum, into hybrid learning classes, virtual departments (NITLE s Sunoikisis, for example), and discussion between classes in time and space.

\section{Discussion boards}

Discussion fora date back to the 1970s. In current teaching practice, they appear either within enterprise-level systems or independently.

Blackboard. A course management system, Blackboard includes several forms of discussion boards. Other CMSes include WebCT, Moodle, and Sakai. Access: http:// blackboard.com/products/Academic_Suite/.

John Suler, "Extending the Classroom into Cyberspace: The Discussion Board." A psychologists view on how to maximize use of discussion boards; appeared in CyberPsychology and Behavior, 7 , 397-403. Access: http://www.rider.edu/ suler /psycyber/extendclass.html.

PHPBB. A widely used open source discussion forum easy to install, support, and use. Access: http://www.phpbb.com/

Worcester Polytech, "Improving the Use of Discussion Boards." This set of practical guidelines is informed by scholarship and applies to a variety of platforms. Access: http://www.wpi.edu/Academics/ATC /Collaboratory/Idea/boards.html.

\section{Web publishing}

Dreamweaver. Few teachers and students produce Web content by hand-coding HTML. Instead they use Web editors, of which Macromedia s Dreamweaver remains the most popular. Access: http://www.adobe. com/products/dreamweaver/.

Euclid's Elements, Interactive Presentation. A Furman University project, 
this series of pages constitutes a tutorial taking students through a classical math text. Access: http://math.furman.edu/ jpoole /euclidselements/euclid.htm.

Salem Witch Trials Documentary Archive. A very rich set of documents for study. Access: http://etext.virginia.edu /salem/witchcraft/home.html.

Virtual Seminars for Teaching Literature. Oxford made a vast WWI archive available for teaching by publishing it to the Web through a user-generated hypertext engine. Access: http://www.oucs.ox.ac.uk /ltg/projects/jtap/.

Visual Elements Periodic Table. A ne visualization from the Royal Society of Chemistry. Access: http://www.chemsoc.org/ viselements/pages/pertable_a.htm.

\section{Wikis}

Google Docs. Google purchased a wiki hosting project, then integrated it within their suite of linked services. Access: http://docs. google.com/.

Jim Giles, "Internet encyclopaedias go head to head." A controversial and inuential study nding Wikipedia and Brittanica entries to have comparable error rates. Nature December 2005-March 2006. Access: http://www.nature.com/news/2005/051212 /full/438900a.html.

Pmwiki. Many wiki packages are available for users to download and host. Pmwiki is one good example of many, offering elegance and ease of use. Access: http://www. pmwiki.org/.

Socialtext. Wikis may also be externally hosted. Socialtext offers varying rates depending on scale. Access: http://www. socialtext.com/.

The Romantic Audience Project. Offered several years at Bowdoin College, this English literature experiment let students create an open mini-encylopedia of British literature around 1800. Access: http://ssad. bowdoin.edu:8668/space/snipsnap-index.

"The Romantic Audience Project: A Wiki Experiment." Romantic Circles, December 2004. Peer-reviewed scholarship of pedagogy. Access: http://www.rc.umd. edu/pedagogies/commons/innovations/rap /toc.htm.

Wiki evaluation tools. This article from Dossiers technopedagogiques links assessment to wiki capabilities. Access: http:// www.profetic.org:16080/dossiers/article. php3?id_article=973.

Wikipedia. The most widely recognized wiki project is the Wikipedia, a publicly editable encyclopedia. Access: http:// en.wikipedia.org/wiki/Main_Page).

\section{Blogging}

Blog platforms and projects have proliferated enormously in the past half-decade, due, in part, to ease of use.

Barbara Ganley at Middlebury College. This faculty member blogs about her work, reflects on blogging, and teaches with blogs in a variety of innovative ways. Her blog contains links to all of these. Access: http://mt.middlebury.edu/middblogs /ganley/bgblogging/.

Blogger. A very popular and basic blogging tool, hosted by a company owned by Google, Blogger is a ne starting point. Basic accounts are free. Access: http://blogger. com.

LiveJournal. This service adds more functionality to blogging, including agging content for emotional state, and aggregating friends through links. It is hosted externally. Basic accounts are free. Access: http://livejournal.com.

WordPress. Some blog services can be run by users themselves, on servers they own or have access to. WordPress has emerged as a leading example of this, offering a great deal of functionality and exibility. Access: http://wordpress.org/.

\section{Sample blog-based classes and projects}

Blogging the World. A multiblog project connecting students studying abroad with campus, home, and world. Access: http://mt.middlebury.edu/middblogs/ganley /bloggingtheworld/

Library-supported blogs at the University of Minnesota. Librarians have been 
blogging about library content, events, and issues. Some support blogging beyond the library, such as the University of Minnesota s campuswide initiative. Access: http://blog. lib.umn.edu/.

Religious studies class. A philosophy course at Ursinus College used multiple blogs, including one for the syllabus and class news and one for each student. Access: http:// religious-studies.blogspot.com/.

Spivak Seminar at Crooked Timber. A group of scholars designed a two-week seminar around an important essay, blogged their discussions, then made the entire aggregate available as a single download. Access: http://www.long-sunday.net/spivak/.

Student blogs at Centenary College. Some institutions have published sample student blogs as examples of student life. Centenary College of Louisiana is one case of this. Access: http://www.centenary.edu/blogs.

The Pepys Diary. This innovative project presents a classic 17th-century British literary document, a diary of London life. The blog format makes the content more accessible, while enriching it further through comments. Access: http://www.pepysdiary.com/.

\section{Social images}

Documenting Lewis Elementary. This school used Flickr to store, publish, and share images recording its teaching and learning experience. Access: http://www. ickr.com /photos/lewiselementary/.

Flickr. While other social image projects exist (Photobucket, 23HQ), Flickr remains the most prominent, and consistently innovates. It pioneered user-generated folksonomic image tagging. Access: http:// ickr.com.

Steve: Exploring folksonomies and museums. This multi-museum, longterm project has studied user-generated tagging from a curatorial perspective. The site archives papers and other records of Steve s work, which represent many breakthroughs and advances. Access: http://www. archimuse.com/research/steve.html.

The Teaching Files: X-Rays. A resident physician uses Flickr images to teach reading X-ray photos of the human body. Access: http://www. ickr.com/photos /mjagbayani/sets/895629/.

\section{Social bookmarking}

Del.icio.us. This service lets users store bookmarks on the Web, tag them, then share their discoveries with other users. Accounts are free, and the project owned by Yahoo! Access: http://del.icio.us.

H2O. There are social bookmarking services created by academics. Harvard s $\mathrm{H} 2 \mathrm{O}$ is aimed at faculty. Access: http://h2obeta.law. harvard.edu/home.do.

PennTags. Penn State University s library system created a user-tagged system for library content. Access: http://tags.library. upenn.edu/.

\section{Podcasting}

Bryan Alexander, podcasting schematic. A diagram of podcast creation, publication, and consumption. Published to Flickr, and discussable there. Access: http://flickr. com/photos/bryanalexander/204078355/.

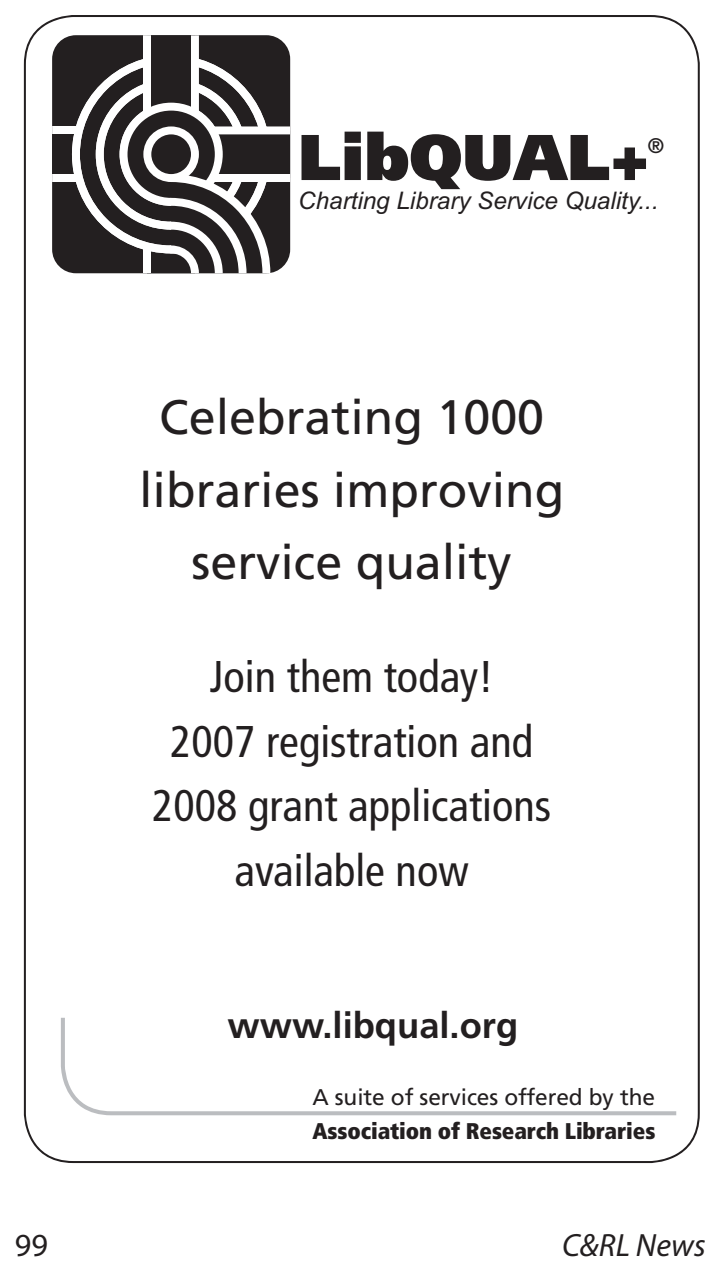


Gardner Campbell, "There's Something in the Air: Podcasting in Education." Educause Review, November/December 2005, Volume 40, Number 6. The best article on pedagogy of podcasting. Access: http://www. educause.edu/ir/library/pdf/erm0561.pdf.

Sample podcasting classes and projects

Artmobs. A Marymount Manhattan College class created its own MP3 tours of a museum, using podcasts to re ect on primary materials (art) and secondary (the museums own tour). Access: http://mod. blogs.com/art_mobs/.

Berkeley Groks science podcasts. These student-created podcasts discuss science issues and often include university faculty interviews. Access: http://www.groks.net/.

Chemistry at Bryn Mawr. Professor Michelle Frankl recorded her lectures within class session, then podcast them for student use within and beyond her classroom. Access: http://chemistry221.blogspot.com/.

Digital Media for Management and Marketing. This business textbook migrated entirely to podcast, appearing in small pieces. Access: http://www.baclass.panam. edu/mana3333/.

John Donne podcasts. An English professor podcasted careful readings of 17 thcentury poetry, in order to draw out syntactic complexities. Students then podcasted back, demonstrating their learning. Access: http:// www.gardnercampbell.net/blog1/?p=372.

Out of the Past. A classic example of social software enabling the public intellectual, this podcast is cocreated by a $\mathrm{lm}$ studies professor, allowing him to share academic insights into a genre with the larger world. Access: http://outofthepast. libsyn.com/.

smARThistory. This blog-based class uses podcasts to introduce art topics and works, while also recording student reactions. Access: http://www.smarthistory.org/blog/.

We Media" class at Carleton College. This media studies course explored popularly generated and social media using podcast creation to develop student work.
Access: http://www.ratchetup.com/we _media_podcast/.

Campus podcasting examples

Allegheny College. Access: http:// webtools.allegheny.edu/podcast/.

Bowdoin College. Access: http://www. bowdoin.edu/podcasts/.

Lafayette College Soapbox. $A c$ cess: https://ww2.lafayette.edu/ soapbox /podcast.

Wofford College. Access: http://www. wofford.edu/interactive/podcasts.asp.

\section{Virtual worlds}

The Croquet Project. This ambitious effort, designed by academics, seeks to create an open-ended space for discussion and exploration. Access: http://www. opencroquet.org/.

Second Life. Virtual environments inhabited socially by multiple users are increasingly of pedagogical interest. Second Life has won public attention through its innovative combination of user-generated content and open-ended nature. Access: http://secondlife. $\mathrm{com} /$.

Second Life Education Wiki. Perhaps the best site for aggregating teaching and learning practices with Second Life. Access: http://www.simteach.com/wiki/index. php?title=Second_Life_Education_Wiki.

\section{Journals}

Academic Commons. This collaborative publishes articles in issues, along with blogging. Access: http://www.academiccommons. org/.

Educause Review. This journal is published by Educause, the leading educational technology organization in the United States. Topics cover infrastructure, pedagogy, support, and institutional transformation. Access: http://www.educause.edu/er/.

eLearn Magazine. This magazine publishes Web articles steadily during the year. Access: http://www.elearnmag.org /index.cfm.

Innovate Online. This is a peer-reviewed 
publication exploring education and technology. Access: http://www.innovateonline. info/index.php.

T. H. E. Journal. This journal explores many issues concerning technology and education and has done so since 1994. Access: http://www.thejournal.com/.

\section{Blogs about teaching and technology}

There are a great deal of blogs about this subject, and the number grows every month. Participating in the edublogosphere is a ne way to learn about educational technology.

KairosNews. This site focuses on teaching writing with technology, and combines theoretical, practical, and technological perspectives. Access: http://kairosnews. org/.

NITLE Liberal Education Today (LET). The blog for an organization of liberal arts campuses, LET blogs on a variety of issues driven by instructional technologists and teaching faculty. Access: http://b2e.nitle.org/ (full disclosure: author is chief blogger).
Stephen Downes. An energetic, high-quality and quantity blog, offering a potent mix of news and thoughtful commentary. Access: http://www.downes.ca/news /OLDaily.htm.

Will Richardson. Formerly an awardwinning high school teacher, Richardson is one of the leading thinkers about networked learning and the read/write Web. Access: http://weblogg-ed.com/.

\section{Conferences}

Educause Annual Conference. Educause hosts an enormous annual conference, the largest one for the intersection of technology and education. Access: http://www. educause.edu/conference/annual/.

Educause Learning Initiative. This Educause division focuses on teaching and learning. Access: www.educause.edu/eli.

New Media Consortium. This organization focuses on digital media and teaching. The annual conference is complemented by regional ones. Access: http://www.nmc.org /events/2006summerconf/index.shtml. $\not 2$

\section{SpringerLink accelerating the world of research}

\section{springerlink.com}

\section{Introducing \\ Springer eBooks}

Spend less time searching and more time researching.

- More than 3,000 New eBooks and eReference Works Every Year

- Ownership Business Model

- Unlimited Simultaneous Use

- Grouped in 12 subject specific Online Libraries

- Collection comprises Textbooks, Monographs, Handbooks, Major Reference Works, and more

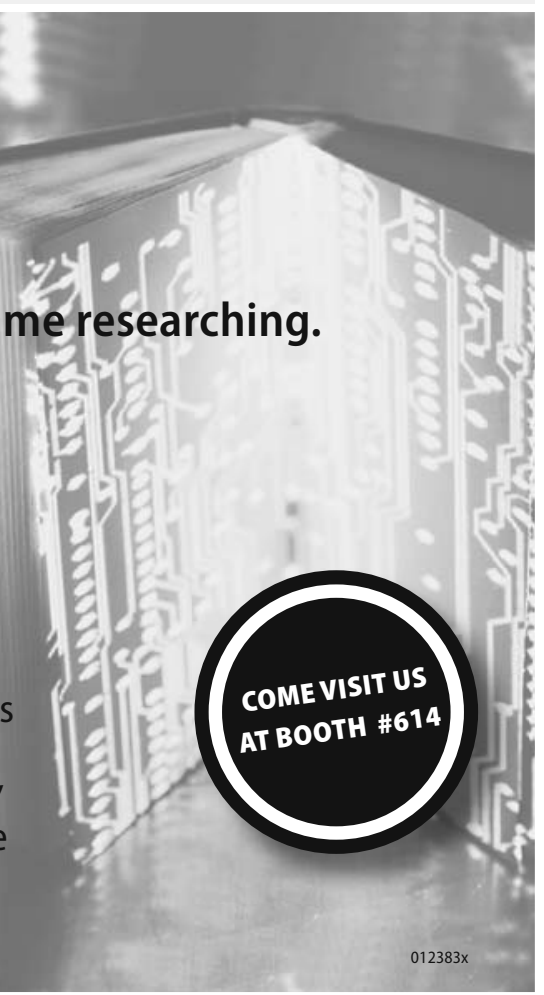

